\title{
Riscos na arrematação de imóvel residencial em leilão
}

\author{
Risks in the tender of residential property in auction \\ Riesgos en la licitación de propriedade residencial en subasta
}

Vanessa Zavoiski

ORCID: https://orcid.org/0000-0002-8793-2139

Fundação Estudos Sociais do Paraná, Brasil

E-mail: vanessa.zvsk@ hotmail.com

Caroline Samara Garcia Sales

ORCID: https://orcid.org/0000-0002-8630-056X

Fundação Estudos Sociais do Paraná, Brasil

E-mail: carolinesamara_snp@hotmail.com

Marinei Guarise

ORCID: https://orcid.org/0000-0001-9516-0506 Fundação Estudos Sociais do Paraná, Brasil Universidade Regional de Blumenau, Brasil E-mail: mariguarise@yahoo.com.br

\begin{abstract}
Resumo
No presente contexto, a procura por imóveis com preço abaixo do valor de mercado, tem tornado o leilão judicial uma opção atrativa para a aquisição de bens. Nesse sentido, este artigo visa demonstrar de forma sucinta quais são os riscos mais comuns que o arrematante terá ao adquirir um imóvel residencial por meio de leilão judicial. $\mathrm{O}$ assunto tem amplo panorama jurídico e múltiplas regras administrativas, que ao arrematante é de suma importância sua análise, planejamento e conhecimento prévio. A grande maioria dos imóveis leiloados está ocupado, seja com o proprietário, inquilinos, terceiros ou invasores. Esse cenário gera de imediato uma preocupação aos compradores, pois muitas vezes, os direitos do arrematante são desconhecidos. A presente pesquisa apresenta uma explicação do funcionamento dos leilões e análise dos fatores que devem ser previamente analisados e verificados antes da arrematação. Por meio dos achados evidenciados na pesquisa possível observarem que o conteúdo apresentado não esgota o tema, pois diversidade da interpretação e entendimento do judiciário é particular de cada processo, conforme evidenciado pelos entrevistados. Por meio do presente estudo pode-se concluir que o apesar de o leilão judicial ter se tornado uma forma acessível de aquisição imobiliária, entretanto, nem sempre o desembaraço do bem trâmita de forma rápida e tranquila.
\end{abstract}

Palavras-chave: Arrematação; Imóvel; Leilão; Execução; Judiciário; Informação; Conhecimento.

\begin{abstract}
In the present context, the demand for properties with a price below market value, has made the judicial auction an attractive option for the acquisition of goods. In this sense, this article aims to succinctly demonstrate which are the most common risks that the bidder will have when acquiring a residential property through a judicial auction. The subject has a broad legal panorama and multiple administrative rules, which for the bidder is of paramount importance to its analysis, planning and prior knowledge. The vast majority of auctioned properties are occupied, whether with the owner, tenants, third parties or invaders. This scenario immediately generates a concern for buyers, as the rights of the bidder are often unknown. This research presents an explanation of the functioning of auctions and an analysis of the factors that must be previously analyzed and verified before the auction. Through the findings evidenced in the research, it is possible to observe that the content presented does not exhaust the theme, as the diversity of interpretation and understanding of the judiciary is particular to each process, as evidenced by the interviewees. Through the present study, it can be concluded that despite the judicial auction having become an accessible form of real estate acquisition, however, the clearance of the property does not always proceed quickly and smoothly.
\end{abstract}

Keywords: Auction; Immobile; Auction; Execution; Judiciary; Information; Knowledge.

\begin{abstract}
o
En el contexto actual, la demanda de inmuebles con precio por debajo del valor de mercado, ha hecho de la subasta judicial una opción atractiva para la adquisición de bienes. En este sentido, este artículo tiene como objetivo demostrar de manera sucinta cuáles son los riesgos más comunes que tendrá el postor al adquirir una propiedad residencial a través de una subasta judicial. El tema tiene un amplio panorama legal y múltiples normas administrativas, lo que para el licitante es de suma importancia para su análisis, planificación y conocimiento previo. La gran mayoría de las propiedades subastadas están ocupadas, ya sea con el propietario, inquilinos, terceros o invasores. Este escenario genera inmediatamente una preocupación para los compradores, ya que a menudo se desconocen los derechos del postor. Esta investigación presenta una explicación del funcionamiento de las subastas y
\end{abstract}


un análisis de los factores que deben ser analizados y verificados previamente antes de la subasta. A través de los hallazgos evidenciados en la investigación, es posible observar que el contenido presentado no agota el tema, ya que la diversidad de interpretación y entendimiento del Poder Judicial es particular de cada proceso, como lo evidenciaron los entrevistados. A través del presente estudio, se puede concluir que a pesar de que la subasta judicial se ha convertido en una forma accesible de adquisición de bienes raíces, sin embargo, la liquidación de la propiedad no siempre se realiza de manera rápida y fluida.

Palabras clave: Subasta; Inmóvil; Subasta; Ejecución; Judicial; Información; Conocimiento.

\section{Introdução}

As trocas de bens são tão antigas quanto à própria sociedade, dos simplesescambos que ocorriam muito antes das grandes navegações, até a venda de um imóvel em detrimento de valor pecuniário, já no período mercantil, a barganha já existia. Com o tempo essas transações de oferta e demanda foi se aperfeiçoando, até surgir a prática do leilão. De acordo com o site Leilões Judiciais (2021), pesquisadores alegam que os primeiros leilões teriam acontecido na Babilônia, especificamente no século $\mathrm{V}$ antes de Cristo.

Nos últimos anos, a busca pela modalidade do leilão para adquirir a casa própria foi se intensificando, análises diferentes acerca dos prós e contras desta prática foram aumentando no mesmo tempo em que crescia a divulgação do negócio. Daí a importância de se realizar um exame aprofundado acerca das nuances do leilão, como funciona, em relação aos impostos envolvidos, as regrase legislações relacionadas, bem como as vantagens e riscos inerentes à modalidade.

Nesse sentido, ao se optar por essa modalidade de compra é de suma importância verificar atentamente as regras específicas do leilão. Para Guimarães (2017), é necessário realizar o levantamento de todos os problemas processuais para a avaliação do risco que envolve a compra do bem. Portanto, esta pesquisa tem por objetivo divulgar a alternativa da aquisiçãode imóvel por meio da arrematação em leilão judicial, bem como as nuances queenvolvem a prática do negócio, proporcionando, de acordo com Guimarães (2017), o conhecimento dos acontecimentos mais comuns durante o processo. Para atingir o mencionado objetivo, seguindo os preceitos de Gil (2019), a pesquisa será construída mediante fundamentação bibliográfica, abrangendo aspectos jurídicos sobre o tema e por meio de questionários com profissionais diretamente ligados à prática do leilão. A intenção é que com esse conjunto de fontes de informações sobre o assunto, a pesquisa proporcionará um real cenário deste estilo de negócio.

Além disso, o presente estudo visa também disseminar os reais prós e contras característicos dessa modalidade, a fim de desmistificar quaisquer crenças, de acordo comLecioli (2020), que considerem a aquisição via leilão uma forma de negócio que envolveriscos desconhecidos e custos adicionais. Também abordaremos neste artigo, legislação específica exposta no Novo Código de Processo Civil (2015), para melhor fundamentação do regimento jurídico aplicado aos leilões, inclusive, as particularidades envolvidas que podem anular a venda, garantir a posse do imóvel por meio de recursos, acordo ou outro meio jurídico disponível.

Sendo assim, o presente estudo se justifica pela necessidade de expandira modalidade de compra e venda de imóvel por meio de leilão, assim como situações e medidas importantes que, conforme Abelha (2019) antecede a arrematação de imóvel residencial, a fim de propagar as pessoas o entendimento adequado sobre o assunto. Por fim, esta pesquisa visa contribuir com o conhecimento quando a opção por aquisição de imóveis se der através de arrematação em leilão judicial, visto que ainda existem crenças, segundo Lecioli (2020), que consideram a aquisição via leilão uma forma de negócio que envolve riscos desconhecidos e custos adicionais.

\section{Revisão da Literatura}

\subsection{Aspectos introdutórios do leilão}

Segundo Nascimento (2012) o leilão é uma espécie de transação de bense serviços, guiada pela lei da oferta 
e demanda, no qual o preço é alcançado por meio do maior lance ofertado pelos participantes do negócio.

O evento mais simples que ocasiona em um leilão, conforme Nascimento (2012) ocorre quando um indivíduo põe à venda um bem e há mais de uma pessoa interessada na aquisição, nesse caso, o impasse de quem irá adquirir o bem é solucionado mediante leilão, no qual quem efetivar a melhor proposta arrematará o bem. De acordo com Durães (1997), as normas que regem os leilões são de crucial importância, dado que direcionam a estratégia adotada, as propostas, alémde determinar a alocação dos bens leiloados, assim, necessário atenção ao escolhera categoria do leilão a ser executado para a venda de um bem específico.

Ainda, para Durães, o estudo acerca dos leilões estabelece quatro tipos básicos de leilões competitivos utilizados para a venda de bens e serviços, citados a seguir: Leilões abertos e leilões fechados, sendo o primeiro dividido entre o leilão ascendente, conhecido como leilão inglês e leilão descendente, conhecido como leilão holandêse o segundo, dividido entre leilão de $1^{\circ}$ preço e leilão de $2^{\circ}$ preço, conhecido como leilãoVickrey.

Partindo de um preço mínimo estabelecido para um bem, segundo Durães (1997),os participantes indicam seus lances, no decorrer do leilão no tempo em que os preços vão se elevando, os arrematantes potenciais vão se retirando da competição, sendo o valorfinal atingido quando restar apenas um participante. Uma qualidade do leilão inglês, segundo Nascimento (2012), é que durante todo o processo todos os participantes possuem ciência do valor atualizado do bem e, assim, conseguem reavaliar suas estratégias e/ou propostas de preço.

A fim de corroborar com o exposto, apresenta-se a seguir, na Figura 1, o gráfico de Durães (1997), demonstrando o funcionamento do leilão inglês para bem único. Neste gráficoé possível observar que o valor inicial sofre acréscimos de lances de forma exponencial devido à concorrência entre interessados participantes do pregão, chegando ao lance final, superior ao valor de avaliação, vejamos:

Figura 1 - Leilão inglês - bem único.

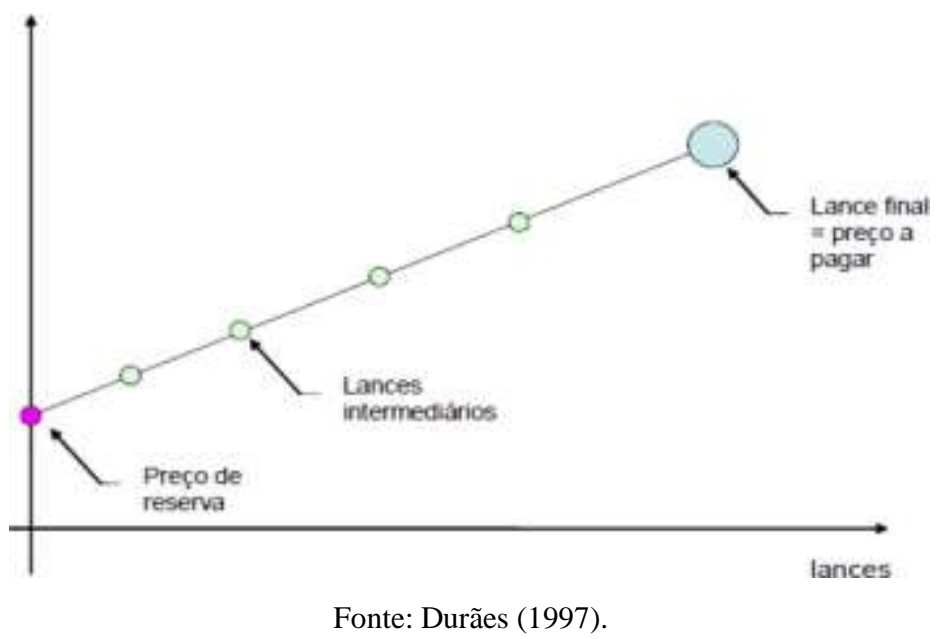

Com o passar dos anos essa modalidade de compra e venda intitulada de "leilão"foi crescendo e sendo abraçada por muitas pessoas físicas e jurídicas. O referido negócio,que cada vez mais ganha espaço no mercado de venda imobiliária, teria se originado, segundo o site Leilões Judiciais (2021), na Babilônia, especificamente no século V antes de Cristo. Uma notícia recente divulgada pelo site Economize do R7 (2020), divulgou que em 2020 o número de imóveis à venda em leilões judiciais cresceu cerca de $80 \%$ se comparado aos anos anteriores, ocorre que a crise econômica causada pela covid-19 acarretou em um crescimento elevado de imóveis consolidados e retomados pelas instituições financeiras.

A notícia reforça que, na tentativa de regularizar o débito em aberto, os imóveis registrados como garantias são colocados a leilão judicial, com o intuito de conseguir liquidez com a venda, pelo maior preço ofertado, para saldar 
integralmente ou parcialmente a dívida do cliente bancário. Portanto, o aumento da inadimplência reflete diretamente na oferta de bens em leilões nos últimos anos. Além do exposto, de acordo com o site Economize do R7 (2020), com as boas oportunidades e baixos preços, a arrematação de imóvel por meio de leilões judiciais tornou-se uma opção de bom negócio, sendo registrado um aumento relevante de $46 \%$ no número de arremates comparados ao ano anterior.

Segundo Bastos (2019), muitas pessoas têm curiosidade e interesse em participar de pregões, entretanto, uma das barreiras que impedem uma maior participação da população em leilões é a falta de conhecimento e a insegurança do comprador. Os principais fatores da pouca participação das pessoas, conforme Bastos (2019), decorrem da complexidade do negócio jurídico, da carência de conhecimento sobre o funcionamento da arrematação, insegurança jurídica perante as decisões judiciaise a morosidade do Judiciário. Nesse sentido, diante dos empecilhos mencionados no parágrafo anterior, nos próximos tópicos abordaremos sobre as ações que resultam na apreensão/consolidação do imóvel, bem como sobre as etapas a serem seguidas para a arrematação de um bem em leilão, enfatizando uma abordagem sobre os riscos.

\subsection{Ações que resultam na venda de um bem em leilão}

Inicialmente, cabe mencionar que nos contratos de financiamento imobiliário, frequentemente o bem adquirido é atrelado como garantia do negócio, reforça Gonçalves (2018, p. 30), “Aquele que deu o bem em garantia real de uma dívida torna-se responsável, até o limite do valor do bem, pelo pagamento da dívida".

Ademais, na referida situação, o devedor assume uma dívida e, portanto, o imóvel se torna a garantia da execução em caso de inadimplência no financiamento (descumprimento da obrigação de pagar/liquidar as parcelas avençadas em contrato). O meio processual utilizado para realizar a transferência forçada dos bens do devedor à terceiros é a execução das obrigações por coisa certa.

Para Venosa (2021, p. 66) "o verbo dar deve ser compreendido mais amplamente como ato de entregar. Certa será a coisa determinada, perfeitamente caracterizada e individuada, diferente de todas as demais da mesma espécie". Sendo assim, quando inadimplente, o bem dado em garantia é posto à execução. Nessa linha, complementa Azevedo (2001, p.107) “execução é a palavra sinônima de pagamento, solução, implemento, adimplemento dentre outras". O meio para alcançar o dinheiro que será entregue ao executante é a arrematação.

Segundo Guimarães (2017), os casos de inadimplência encontram seu caminho no Poder Judiciário. Segundo capítulo IV da Lei nº 13.105 de 16 de março de 2015, realiza-se a expropriação de bens do executado, que consiste na adjudicação, alienação ou apropriação de frutos e rendimentos e de outros bens, cujo objetivo é a obtenção do pagamento de uma quantia expressa em valor monetário. Para a liquidação da dívida sendo parte deste processo, os bens dados em garantiasão divulgados em editais para a ocorrência do Leilão ou Praça, resume Kronberg (2018), trata-se de contrato de venda, à pessoa que melhor preço oferecer.

Ocorrendo a arrematação, para Abelha (2019, p. 441) "marca o "início do fim" doitinerário executivo que se dá com a "compra" de bens penhorados em leilão público. Com o produto (dinheiro) arrecadado pela alienação forçada de seus bens haverá o pagamento da quantia devida.".

\subsection{Etapas na arrematação do bem e os riscos envolvidos}

Iniciado o processo de execução, o bem é divulgado via edital elaborado pelo leiloeiro, que fará a divulgação. A publicação via jornais, sites e editais, contribuirá parao comparecimento de licitantes. Neste ensejo, reforça Kronberg (2018), que não poderá ser realizado nenhum leilão, sem que o leiloeiro efetue a divulgação. De outro lado, segundo Bastos (2019) a avaliação judicial do bem entregueou consolidado e posto a leilão é realizada pelo oficial de justiça, de acordo coma realidade de mercado, por meio de um laudo constando suas condições de conservaçãona vistoria. 
Já no ato dos lances no pregão, o arrematante deve evitar ofertar preço menor do que o valor de avaliação, podendo o lance não ser aceito pelo Juiz. Reforça o artigo 891 do Novo Código de Processo Civil (2015, p.193):

Art.891. Não será aceito lance que ofereça preço vil.

Parágrafo único. Considera-se vil o preço inferior ao mínimo estipulado pelojuiz e constante do edital, e, não tendo sido fixado preço mínimo, considera-sevil o preço inferior a cinquenta por cento do valor da avaliação.

Com relação ao investimento, o primeiro passo, a ser observado é o pagamento, oqual deve ser efetivado até o final do dia seguinte ao término do leilão, devendo ser observada as particularidades no edital. Regido no Novo Código de Processo Civil (2015, p. 193) no art. 892 do "Salvo pronunciamento judicial em sentido diverso, o pagamento deverá ser realizado de imediato pelo arrematante, por depósito judicial ou por meio eletrônico".

Para Kronberg (2018), quanto aos valores que devem ser desembolsados, além do valor do arremate do bem adquirido, deve ser levado em conta a comissão do leiloeiro, ou porcentagem, regularmente determinada em Lei. A base legal para os honorários do leiloeiro se encontra no Decreto Lei no 21.981, de 19 de outubro de 1932, especificamente no Art. 24. Prevendo a taxa de comissão estabelecida por convenção prevista em 5\%. Quando a aquisição de um bem imóvel se der via leilão, esta modalidade de compra requer análises que visam prever possíveis riscos para a efetivação do negócio.Além do valor do lote, é de suma importância verificar atentamente as regras específicas de cada leilão. Ressalta Guimarães (2017), que para a avaliação do risco na arremataçãoem leilão, é necessário analisar de forma ampla e realizar o levantamento de todos os problemas processuais.

Alguns leilões são livres de ônus, por isso, outro ponto importante é verificarse há impostos pendentes com o Estado. Segundo Bastos Junior (2019), quando existir ônus referente ao imóvel leiloado, o arrematante poderá desistir da arrematação se provartal fato em até 10 dias da assinatura pelo juiz do auto de arrematação positivo. Conforme exposto por Gonçalves (2018), assinado o auto de arrematação pelo juiz, baseado no art. 903 do CPC, a arrematação será considerada, perfeita e acabada. O autor enfatiza que, a partir da arrematação será expedida a carta para registro do imóvel no Cartório de Registro de Imóveis.

Desta forma, no Código Civil (2002), para obter o domínio do bem imóvelé necessário o registro desse ato em cartórios, nos termos dos artigos 1.227 e art. 1.245, pois, os direitos reais sobre imóveis só se adquirem com o registro no Cartório dos referidos títulos. Para a garantia do direito de propriedade o registro é necessário par consolidara propriedade do bem. Explica Abelha (2019, p. 444) "é preciso que a cartade arrematação contenha elementos necessários à realização do registro. Assim, a carta de arrematação deve conter a descrição do imóvel, com remissão à sua matrícula.”

Segundo a cartilha do arrematante, disponível no site do JE Leilões (2021), caso o arrematante seja inadimplente e não arque com o pagamento ou não deposite os valores corretamente, as penalidades impostas são a perda do sinal, das custas, despesas e comissão. Além de arcar com uma multa, pode responder inquérito criminal por frustrar venda em hasta pública e atrasar o fim do processo. Para Lecioli (2020), visando a segurança da arrematação, uma forma sugestivade evitar que os efeitos incertos geram o cancelamento das arrematações, expõem que nosso ordenamento jurídico merece modificações que visem a segurança da arremataçãoe a eficiência da execução, ainda vista como tormentosa. Ainda, reforça o autor que as leis seguem a evolução e necessidade da sociedade de regular as relações sociais, ou seja, são passíveis de modificações em detrimento dos eventos.

Conforme Comazzetto (2021), os bens postos a leilão, tratando-se de expropriação forçada contra a vontadedo executado, na arrematação pode ocorrer a evicção, que consiste na perda da coisa por sentença judicial. O site Normas Legais (s.d.) explica "nos contratos onerosos, o alienante responde pela evicção. Subsiste esta garantia ainda que a aquisição se tenha realizado emhasta pública". Pode ocorrer por decisão judicial, ou ato administrativo que reconheça o direito de posse a terceiro, 
por uma situação anterior à compra. Tendo como proteção o art. 477 do Código Civil, o adquirente poderá recobraro que pagou pela coisa. É de direito do arrematante à indenização por eventual evicção sobre o bem adquirido, por hasta pública, devendo ser verificada a previsão em edital.

Além de riscos materiais, existem também os riscos no âmbito processual. Para Guimarães (2017) "O risco do leilão deixa de ser apenas aqueles de ordem material do bem (posse e estado de conservação), como também aqueles existentes no âmbito processual, ou seja, sobre todo o procedimento realizado". Visando diminuir as frustrações do arrematante, de modo a garantir a efetividade da compra do bem arrematado, não é permitido o pagamento da dívida, ou seja, a remissãoda execução após a realização do leilão. Salvo em dois dispositivos, expostos Novo Código de Processo Civil (2015, p. 189), quais sejam:

Art. 902. No caso de leilão de bem hipotecado, o executado poderá remi-lo atéa assinatura do auto de arrematação, oferecendo preço igual ao do maior lanceoferecido. (Novo Código de Processo Civil, 2015, p.196)

Art. $877 \S 3^{\circ}$ No caso de penhora de bem hipotecado, o executado poderá remi-lo até a assinatura do auto de adjudicação, oferecendo preço igual ao da avaliação, se não tiver havido licitantes, ou ao do maior lance oferecido.

No caso de arrematação de imóvel residencial ocupado, segundo vídeo explicativono canal da TV CRECI SP, para Yougui (2017), é responsabilidade do arrematante a retirada dos ocupantes. Confirma que deve ser providenciada uma notificação extrajudicial para que os moradores desocupem o imóvel que foi arrematado. Enfatiza que a tentativa de acordo é considerada a melhor solução, evitando gastos em uma ação de imissão de posse, o que por certo estenderia o prazo de usufruir da posse do bem adquirido.

Explica Yougui (2017), que em muitas situações, ocorre à resistência dos atuais ocupantes em se retirar do imóvel. Assim, vencido o prazo estipulado em notificação,se o possuidor ainda não conseguir ocupar o imóvel é necessária à entrada de uma ação de despejo para a imissão da posse. Ante o mencionado, é possível aferir que existem vários fatores de incertezas durante o processo de arrematação, sendo garantida ao arrematante a entrada com ações autônomas para reaver o bem, seja por meio de desfazimento ou a indenização de seu direito.

\section{Metodologia}

Segundo Michel (2015), metodologia é um caminho desenhado com a finalidade de se chegar a um determinado objetivo. De acordo com ele, metodologia é a fórmula utilizada para resolver um problema que já existe e esclarecer eventuais dúvidas que permeiam o assunto. Nesse sentido, os critérios metodológicos dessa pesquisa são caracterizados comosendo de cunho exploratório, efetuado por meio de questionários, com a abordagem qualitativa do problema. Gil (2019) menciona que a pesquisa exploratória tem a finalidade de esclarecer conceitos e ideias sobre um assunto, com a intenção de expor uma visão geral de um tema pouco explorado.

Como brevemente mencionado no parágrafo anterior, a pesquisa será qualitativa, uma vez que se busca um maior conhecimento sobre o tema tratado, levandoem consideração a resposta de pessoas com experiência no ramo discutido, divulgando suas vantagens e os riscos inerentes ao negócio. A coleta das informações foi realizada por meio de questionários, conforme Martins e Theóphilo (2007), o referido instrumento é uma das formas que o pesquisador tem de obter informações. Nesse procedimento as perguntas sobre o tema tratado são diretamente realizadas aos abordados, sendo suas respostas utilizadas como alicerce teórico no processo de pesquisa.

Diante do exposto, o presente artigo irá se utilizar de questionários abertos, aplicados respectivamente ao leiloeiro, juiz e pessoa física já participante do negócio,a fim de contribuir com o estudo acerca dos riscos na arrematação de imóvel residencial em leilão. O questionário realizado a cada um dos participantes foi composto por 05 a 07 perguntas, sendo que as 
perguntas tiveram nuances diferente, e, realizadas de acordo comexpertise e vivência de cada profissional, conforme se verifica no Apêndice do presenteestudo.

O leiloeiro aqui designado "leiloeiro" formou-se em 1999 em Direito, atuante no campo desde 2000, é Leiloeiro Público Oficial matriculado e habilitado pela Junta Comercial do Estado do Paraná e Leiloeiro Rural pela Federação de Agriculturae Pecuária do Paraná. Além da opinião do leiloeiro, esse artigo terá suporte das opiniões de um juiz e depersona atuante em leilões, sendo eles: o "juiz" formado na UEL atuando há 32 anos no cargo, e a pessoa física "arrematante" participante de leilões há 17 anos.

Vale salientar, que os questionários foram aplicados às profissionais atuantes na cidade de Curitiba, escolhidos devido à viabilidade de acesso para com esses profissionais, que contribuíram a partir de suas experiências práticas sobre os riscos na arrematação de imóvel residencial em leilão. Por fim, com o leiloeiro e o arrematante buscou-se coletar informações acerca dos processos de arrematação de bem em leilão. Já com o juiz, optou-se por elencar as situações mais corriqueiras evidenciadas nos processos envolvendo a venda de imóveis por leilão, os maiores riscos observados e como, na opinião do magistrado, seria possível evitar tais dissabores. Aspectos que consequentemente culminaram na liberação do emaranhado de processos estagnados no judiciário.

\section{Resultado, Análise e Discussões}

Com os questionários realizados obteve-se um panorama dos riscos mais comunsenvolvidos no negócio. E com base nas respostas obtidas apurou-se que o leilão judicial se caracteriza como um investimento de prazo indeterminado ou longo prazo. No qual existe morosidade por parte do judiciário para o andamento do processo, sendo o tempo para exercer a posse do imóvel leiloado imprevisível, variando de meses a anos. Os demais riscos identificados, variam desde a suspensão da venda do bem leiloado no decorrer do processo de execução a gastos extras com a desocupaçãoem caso de imóvel ocupado, além disso, identificou-se que muito das controvérsias existentes acerca da temática aqui apresentada, existe pela falta de conhecimento sobre o assunto.

Neste contexto, questionado sobre os motivos e o tempo médio que um imóvel hipotecado é colocado a leilão, o "leiloeiro" explica:

(...) o tempo médio para que um processo seja sentenciado, e que após recursoso inadimplemento se configure, o bem seja avaliado e o leilão marcado, é de 5 anos. Um bem imóvel pode ir a leilão por vontade do vendedor, constrição judicial ou por cláusula penal em contrato. Será voluptuário quando de livre vontade resolver o vendedor ofertá-lo de forma pública e transparente. É o casodos bens imóveis que são incorporados ao ativo de uma instituição financeira, seja por adjudicação, por dação em pagamento ou mesmo de seu patrimônioe decide-se pela desmobilização. (...)

Levando em consideração a resposta do "leiloeiro", um imóvel pode ser posto a leilão por diversos motivos, dentre eles a incorporação ao ativo da casa bancária em decorrência do inadimplemento contratual. Assim, em um cenário de inadimplência de certo financiamento, o imóvel contratualmente alienado como garantia, é consolidado pela casa bancária e posto a leilãoe assim seguindo os procedimentos da ação de execução. Neste ensejo, o “juiz”, complementa:

Em toda responsabilidade patrimonial que surge, a busca por bens que garantam a dívida é uma realidade. No processo de execução dentro do direitobrasileiro, uma das fases essenciais é a garantia do juízo (penhora), onde o credor pretende alcançar um bem de propriedade do devedor para que seja adimplida a dívida. Assim, o maior motivo é o inadimplemento de uma dívida pré-existente ou então que se constitua por força de ação judicial com o caráter condenatório contra o réu. Na sequência à penhora do bem, o procedimento de leilão é uma consequência natural (...).

Como visto no capítulo anterior, a execução de bens é a via judicial para adimplirdívidas.Deste modo, sendo o leilão 
uma via para liquidar a dívida por meio da ação de execução, o "leiloeiro" reforça na mesma linha de entendimento, que a oferta de imóveisem editais de leilão está associada a inadimplência:

(...) Em se tratando de leilões judiciais, os motivos são os mais diversos, mas em geral a partir da sentença condenatória em que a parte vencida deve pagar a vencedora o valor determinado, se não o faz no prazo, são-lhe penhorados tantos quantos bens sejam necessários para o adimplemento. (...)

Neste contexto, o "juiz" avigora que, ocorrendo a inadimplência, todo imóvel dado em garantia de um contrato de empréstimo/financiamento pode ser levado a leilão:

É uma das características do direito real sobre coisa alheia que um bem ofertado como garantia de uma dívida (hipoteca para bem imóvel e penhor para bem móvel) sirva de cumprimento da obrigação. No caso do processo de execução por dívida hipotecária (por exemplo, contrato de mútuo com garantia hipotecária, onde o devedor indica um bem para garantiro cumprimento da obrigação), o art. 835, $\S 3^{\circ}$, do Código de Processo Civil, diz que: " $\$ 3^{\circ} \mathrm{Na}$ execução de crédito com garantia real, a penhora recairá sobre a coisa dada em garantia, e, se a coisa pertencer a terceiro garantidor, este também será intimado da penhora." Assim, todo imóvel dado em garantia tem esta função protetiva em favor do credor.

De modo contrário, foi questionado ao "leiloeiro" quais os impedimentos para que um imóvel não seja executado em leilão. Explica que se tratando de processo judicial cada esfera do judiciário segue seus ritos específicos:

(...) Para a realização de um leilão de imóvel, segue-se os ritos. (...) Um imóvelnão poderá ser alienado, isto é, estaria impedida a sua venda, em caráter privado, se houver alguma anotação no registro em que não esteja livre e desembaraçado. Já em âmbito judicial não há impeditivos. Evidentemente que havendo ordem judicial diversa o juízo analisará o caso concreto. (...)

Em contrapartida, existem situações diversas que impedem que o imóvel seja levado a oferta em hasta pública ou que no decorrer do andamento processual ocorra a anulação da venda. Para o "juiz" a impenhorabilidade pode ser reconhecida nos casos em que o cônjuge do devedor consiga comprovar que não houve seu consentimento sobre a garantiahipotecária do imóvel. Vejamos:

A Lei $n^{\circ} 8.009 / 1990$ prevê tais hipóteses de impenhorabilidade, mas também traz exceção, como o caso de dívida hipotecária. Nesse sentido é o texto legal:“Art. $3^{\circ} \mathrm{A}$ impenhorabilidade é oponível em qualquer processo de execução civil, fiscal, previdenciária, trabalhista ou de outra natureza, salvo se movido:(...) V - para execução de hipoteca sobre o imóvel oferecido como garantia realpelo casal ou pela entidade familiar; (...). Somente não caberia a penhorae consequente leilão se, por exemplo, o cônjuge do devedor provasse que a garantia hipotecaria foi feita pelo devedor principal sem a sua anuência (cônjuge) ou ainda que não houvesse proveito patrimonial em favor do núcleo familiar. Este é o entendimento dominante no Superior Tribunal de Justiça: "A impenhorabilidade do bem de família hipotecado não pode ser oposta nos casos em que a dívida garantida se reverteu em proveito da entidade familiar."

Posteriormente, visando analisar a oferta e a demanda entre os interessados em arrematar imóveis em leilão e os bens disponíveis, foi questionado ao "leiloeiro" se a maior porcentagem dos imóveis é arrematada:

A maior parte dos imóveis ofertados não costuma haver arrematação, muitas vezes porque na iminência de perder o bem o executado/reclamado/réu paga a dívida, frustrando o leilão, outras porque o valor de avaliação do bem está acima da intenção de compra do mercado.

Ainda o "leiloeiro" explica que, o insucesso nas arrematações também é reflexo do baixo conhecimento detido pelos interessados e a insegurança sobre os riscos desconhecidos:

(...) Outro problema é o desconhecimento dos riscos e oportunidades por grande parte da população (...). 
Tendo em vista, que o processo entre consolidação do imóvel até a sua arrematação é composto por vários atos processuais, cada um com seu tempo e requisitos específicos, não ocorrendo defesa ou suspensão da parte contrária, o tempo estimado entrea arrematação e a posse é de cerca de 6 meses, conforme afirmado pelo "juiz":

(...) Cada ato demanda tempo e requisitos, mas, no geral, da penhora ao leilão(se não houver apresentação de defesa pelo devedor, com concessãode suspensão do processo pelo magistrado), o prazo gira em torno de 06 meses.Em linhas gerais, há a penhora do bem, sua anotação imobiliária, avaliação, prazo para eventual adjudicação pelo exequente (ficar com o bem para ele como troca pela dívida nos limites dos valores), determinação de leilão,expedição de edital, realização do ato (presencial ou eletrônico), arrematação e expedição da carta de arrematação em favor do arrematante.

Sobre outra ótica, o "arrematante" expõem que a morosidade do judiciário é uma das barreiras para uma maior participação das pessoas em leilões. Complementa que,os riscos são maiores tratando-se de leilão eletrônico, pois falhas e lentidão da internet são de responsabilidade do usuário. Vejamos:

Para leilão eletrônico, pode ocorrer oscilação na internet e delay entre os lancesofertados, ou seja, num clique para dar o lance em segundos o lance ofertado pode cobrir de forma automática outros lances que ocorreram de forma simultânea, sendo o risco exclusivamente do usuário. Isso pode resultar na aquisição de um bem indesejado, ultrapassando o valor limite que você previa e pode pagar, passando a ser um prejuízo. Outro risco recai sobreo tempo para exercer a posse, após a compra, é incerto, depende do andamentoprocessual de cada caso, podendo chegar a 8 anos o tempo de espera para usufruir de um bem.

Em vista da experiência prática, o "arrematante" alerta que existe risco de gastos extras não planejados, ou seja, entre a arrematação e a posse pode ocorrer um lapsode informação.

Reforça que as informações mais importantes constam em edital na matrícula do imóvel, porém após os trâmites do leilão, dado o momento de exercera posse do imóvel adquirido, o arrematante pode se deparar com o imóvel invadidoe ocupado por terceiros desconhecidos. No cenário retratado, visando agilidade no processo de aquisição do imóvel, o arrematante pode cooperar com o ocupante do imóvel nas despesas para custear aluguele a mudança e em últimos casos, não ocorrendo acordo amigável, é necessário entradade ação própria para despejo:

(...) tudo consta em edital e na matrícula do imóvel de interesse. Mesmo constando em edital que o imóvel está desocupado, em dias após o leilãoé invadido por terceiros. Uma das sugestões mais indicadas nessas situaçõesé através de conversa amigável. O arrematante deve propor acordo colaborando com a ajuda com a mudança, e até mesmo subsidiar o pagamentode aluguel para os ocupantes se retirarem do imóvel, por exemplo.

Neste ensejo, o "arrematante", conclui que a aquisição de imóveis via leilão judicial é benéfica e considera uma modalidade de negócio vantajosa. De outro lado, pondera ser uma modalidade de investimento de longo prazo e que permite a aquisição de bens com valor abaixo do preço de mercado.

Vejamos seu desfecho ao ser questionado sobre os benefícios da arrematação:

Valor abaixo do mercado. Também, uma forma de investimento de longo prazo.

Ademais, existem ações que podem ser tomadas para desenrolá-lo do processose tornar eficiente e menos moroso. Vejamos o apontamento do "juiz" em seu desfecho:

(...) O novo CPC já prevê de forma minuciosa a realização dos atos necessáriospara garantir a efetividade da penhora até a arrematação, com detalhamentode atos, mas sem perder as garantias constitucionais do devido processo legal,do contraditório e da ampla defesa. Acredito que a agilização pelo magistrado (dando andamento rápido ao processo de execução) por si só já se mostra comoum ambiente de maximização. A ampla publicidade é um diferencial, sendo que hoje em dia os leiloeiros estão muito mais profissionalizados e a tecnologia da informática tem facilitado o acesso aos leilões, sejam eles judiciais ou aindaextrajudiciais. (...)

Com base em todo o exposto, ambos os questionados relataram que os riscos na arrematação existem, dentre eles 
gastos extras, a demora do judiciário e também a possibilidade do cancelamento da arrematação, resultando na dissolução da compra e consequente devolução dos valores pagos pelo arrematante. Portanto, os profissionais reconhecem a existência de riscos na arrematação, porém, como qualquer tipo de negócio que envolve riscos financeiros, a atenção dada, o estudo e análise aprofundada de cada caso, reflete diretamente na minimização dos riscose eventuais prejuízos.

Sendo assim, nesta modalidade de negócio, levam-se em conta as particularidades de cada processo, as nuances de cada oferta de arrematação em leilão e os diferentes caminhos e desfechos processuais.

\section{Considerações Finais}

Perante a forte crise econômica que o Brasil enfrenta, em decorrência da pandemia do coronavírus, a venda de bens residenciais por meio de leilão judicial vem ganhando enfoque na vida dos brasileiros, trazendo à baila discussões acerca dos prós e contrasdo referido negócio, bem como a divulgação dos riscos inerentes à modalidade. Portanto, esta pesquisa teve por objetivo divulgar a opção da aquisição de imóvelpor meio de leilão judicial, bem como as especificidades que norteiam a referida prática, sendo ponte entre o conhecimento dos acontecimentos mais comuns durante o processo e os possíveis participantes desse mercado.

Para atingir o referido objetivo, a pesquisa foi construída mediante fundamentação bibliográfica, citando estudiosos sobre o tema, aspectos jurídicos e legislações que regemo negócio, além disso, o presente artigo contemplou a aplicação de questionários realizados com profissionais diretamente ligados à prática do leilão. A intenção, com esse conjunto de fontes de informações sobre o assunto, foi que a pesquisa constituiria um real cenário deste estilo de negócio, disseminando os reais próse contras característicos dessa modalidade.

Nesse sentido, com base nas pesquisas realizadas e de acordo com as respostas obtidas em questionários alcançados, foi possível compreender que em um financiamentoimobiliário, por exemplo, diante de um cenário de inadimplência contratual, o acertode contas entre credor e devedor é solucionado por vezes mediante via judicial. Se dandopor meio de ação de execução, no qual de um lado há o devedor que perde o bem para saldar sua dívida prometida e do outro há o comprador, ora arrematante, interessado na aquisição do imóvel.

Contudo, nem sempre ações de execução tramitam de forma rápida e tranquila, de acordo com os questionados, o tempo médio para um leilão de bem dado em garantiaé de cerca de cinco anos, além do que, custos adicionais para a efetiva aquisição do imóvel são passíveis de acontecer, deixando a modalidade do leilão frustrada. De outro lado, nesta pesquisa observou-se que existe o interesse de pessoas leigasem participar dos pregões. Porém, em análise aos questionários realizados, nota-se quea aquisição de um bem via leilão judicial ainda é fato inseguro para alguns. Ou seja,o desenrolar do processo judicial é visto como negócio incerto ou duvidoso, pois nas fasesprocessuais, podem ocorrer recursos e até mesmo a anulação da venda do bem, fato frustrante ao arrematante.

Neste ensejo, visando expor o cenário real da prática e vivência de profissionais da área, detentores do assunto, este trabalho pôde ser complementado com opiniõese fatos verídicos, rotineiros do leilão. Em linhas gerais, as respostas dos três questionários aplicados foram similares e abarcaram acontecimentos comuns, não resultando em divergência de opiniões. Compartilham do entendimento de que o processo de aquisição de bem imóvelé geralmente moroso, contando eventualmente com problemas adicionais que podemou não ser previstos, sendo, contudo, de suma importância conhecimento aprofundando sobre o tema e análises pormenorizadas acerca de cada processo.

Por conseguinte, diante da pesquisa realizada, entende-se que diante de vários fatores de incertezas durante o processo de arrematação é garantido ao arrematanteà entrada com ações autônomas para reaver o bem. Seja por meio de desfazimentoou a indenização de seu direito. Não cabendo arcar com prejuízo, por negligência ou imprudência de terceiros no processo. Ou seja, o arrematante tem assegurado à possibilidade de reparação de danos sofridos, sendo uma 
segurança jurídica para que não perca o interesse na participaçãode outras hastas públicas.

Em relação a futuras pesquisas os autores observam que existem várias lacunas de pesquisa que podem ser exploradas visando que se tenha uma melhor compreensão da dinâmica dos leilões de imóveis residenciais, entre elas a questão do perfil dos usuários da aquisição de imóvel por meio do leilao judicial, o que poderia expliar o comportamento do aquirinte em relação aos riscos de aquisição, ainda como sugestão futura de pesquisa, pode ser explorado os passivos contingentes que podem estar inseridos na aquisição de imóveis por meio de leilão judicial por incorporadoras e seu tratamento tanto contábil quanto fiscal.

\section{Referências}

Abelha, M. (2019). Manual de direito processual civil. Grupo Gen-Editora Forense.

Assessoria a leiloeiros oficiais (2021). Origem do Leilão. https://www.leiloesjudiciais.com.br .

Azevedo, Á. V. (2019). Curso de direito civil: contratos típicos e atípicos. Saraiva Educação SA.

Comazzetto, J. (2021). A arrematação judicial através do exercício de direito de preferência.

Durães, M. S. D. (1997). Teoria dos leilões: abordagem comparativa com ênfase nos leilões de títulos do tesouro no Brasil e em outros países. Brasília: Esaf.

Economize (2021).Número de imóveis à venda em leilões cresce até 80\%na pandemia. https://noticias.r7.com/economia/economize.

Gil, A. C. (2019). Métodos e Técnicas de Pesquisa Social. (7a ed.), Editora Atlas SA.

Guimarães, H. D (2021). Perigos e armadilhas processuais dos leilões judiciais. https://www.migalhas.com.br .

Intituto de registro imobilário do Brasil (2021). A alienação fiduciária de coisa imóvel e os leilões após a consolidação da propriedade imobiliária. https://www.irib.org.br .

Bastos, J. O. A. (2019). O Leilão Judicial de Imóveis. Editora Lumen Juris.

Lecioli, R. M. (2020). A arrematação em hasta pública como forma de aquisiçãooriginária da propriedade. https://jus.com.br/artigos/78953.

Leilões, J. E. (2021). Cartilha do Arrematante. Londrina. https://www.jeleiloes.com.br/cartilha-do-arrematante.pdf.

Martins, G. A., \& Theóphilo, C. R (2007). Metodologia da investigação científica para ciências sociais aplicadas. Editora Atlas SA.

Mattos e Silva, B. de (2020). Compra de Imóveis - Aspectos Jurídicos, Cautelas Devidas e Análise de Riscos. Editora Atlas SA.

Michel, M. H. (2015). Metodologia e pesquisa científica em ciências sociais: um guia prático para acompanhamento da disciplina e elaboração de trabalhos monográficos. (3a ed.), Editora Altas SA.

Normas Legais (2021). http://www.normaslegais.com.br .

Novo Código de Processo Civil (2015) - Lei No 13. 105, de 16 de Março de 2015. Editora Manole.

Nascimento, R. L. (2012). Análise dos fatores de influência nas propostas ofertadas nos leilões de transmissão de energia elétrica.

Gonçalves, M. V. Rios (2018). Coleção sinopses jurídicas. Editora Saraiva.

Venosa, S. D. S. (2021). Direito Civil - Obrigações e Responsabilidade Civil. Editora Atlas SA.

Yogui, G., \& Sanchez, J. C (2017). TC CRECI. https://www.youtube.com/watch?v=UafId0YBNOA. 